\title{
Morphological and anatomical evaluation of herbal drugs sold under the name of Gül (Rosa damascena Mill.) in Turkey
}

\author{
Gülsen KENDİR 1* (D), Ayşegül KÖROĞLU 2,3 (D) \\ 1 Süleyman Demirel University, Faculty of Pharmacy, Department of Pharmaceutical Botany, 32260 Isparta- \\ Turkey. \\ 2 Ankara University Faculty of Pharmacy, Department of Pharmaceutical Botany, 06100 Tandoğan, Ankara- \\ Turkey. \\ 3 Ankara University Faculty of Pharmacy, Department of Pharmaceutical Botany, 06100 Tandoğan, Ankara- \\ Turkey. \\ * Corresponding Author. E-mail: kendir08@gmail.com (G.K.); Tel. +90-505-848 9978.
}

Received: 12 August 2020 / Revised: 11 November 2020/ Accepted: 20 November 2020

\begin{abstract}
Rosa damascena Mill. (Rosaceae) is commonly cultivated all over the world due to its fragrances, aromatic and medicinal properties. The plant has been usually utilized as astringent, analgesic, cardiac, and intestinal tonic in traditional medicine. This plant is cultured in mainly Isparta, Burdur, Afyon and Denizli in Turkey and known as "Isparta gülü, Şam gülü, yağ gülü". The goal of this study was to determine whether or the samples in different cities of Turkey sold with the name of "gül" carry qualities appropriate for the definition of herbal drug. Roses samples were obtained from 5 different cities in Turkey. Morphological characteristics of all samples were investigated and their purities were checked. The standard sample was obtained from Isparta. The cross and surface sections from the sepals and petals were investigated and determined. Furthermore, the characteristic anatomical structures of the powdered samples (standard sample and purchased samples) were determined. It was observed that the samples sold were usually composed of rosebuds. In anatomical examinations, unicellular non-glandular trichomes were densely observed in the sepal and petal. Calcium oxalate crystals and glandular trichomes with multicellular head and stalk were seen both the sepal and the petal, but glandular trichomes were seen rarely on the petal. Conical papillae and striated cuticle with epidermal cells were observed on the petal. As a result, it was found that the samples examined did not have the necessary properties to be herbal drugs.
\end{abstract}

KEYWORDS: Rosa damascena; Rosaceae; morphology; anatomy.

\section{INTRODUCTION}

There are over 200 Rosa L. species and more than 18000 cultivars form have been defined. Rosa damascena Mill. (Rosaceae) is one of the most important ornamental species of Rosaceae family, cultivated especially due to its high-value aromatic oil, which is used mainly in perfumery and pharmaceutical industries [1-3]. It is erect, a perennial shrub, deciduous. The plant can reach up to $2 \mathrm{~m}$. The leaves are imparipinnate and consist of 5-7 leaflets. It has several flowers that are deep pink [1, 4].

Since ancient times, the plant has been used as an astringent, analgesic, cardiac and intestinal tonic [3]. It has an important position in Iranian folk medicine and is used for various purposes such as abdominal and chest pains, menstrual bleeding, and strengthening the heart [5]. The oil obtained from flowers has been used for cholecystitis and parodontosis, and also as laxative in Bulgaria phytotherapy [6].

This plant is commonly cultivated all over the world mainly in Turkey and Bulgaria. Turkey is one of the most important rose oil (known as "Turkish rose oil") and rose concrete producers in the world. It is cultured especially in Isparta, Burdur, Afyon, and Denizli, and known as "Isparta gülü, Şam gülü, yağ gülü" $[2,3,7,8]$. Apart from rose oil and rose concrete, some important materials for the cosmetic industry such as bioconcrete, absolute, bioabsolute and rose water are also supplied from rose petals in Turkey [7]. According to the Turkey Statistical Institute data for 2018, $5.355 \mathrm{~kg}$ of fresh roses and $13.592 \mathrm{~kg}$ of essential oils (no

How to cite this article: Kendir G, Köroğlu A. Evaluation of herbal drugs sold under the name of Gül (Rosa damascena Mill.) in Turkey. J Res Pharm. $2021 ; 25(1): 63-71$. 
terpenes) obtained from rose were exported [9]. The plant is traditionally used in Turkey for dental and oral healthcare, various skin diseases, gastrointestinal disorders, and as painrelief, an antiseptic, sedative [10, 11].An infusion prepared from its petals is used against stomach pain, diarrhea and intestinal inflammation in Turkey [12].

It is reported that its flowers especially contain essential oil, anthocyanin, flavonoid, tannin, and phenolic acid [13-19]. It has displayed diverse biological and pharmacological activities. Anticancer, anticholinesterase, anti-inflammatory, cytotoxic, cytoprotective, antioxidant effects of the flowers have been shown with in vitro studies [14, 16, 17, 20-23]. Anti-inflammatory, neuroprotective, antidepressant, antidiabetic, antiplasmodial effects of them have been shown in animal models [22, 24-27]. Biological activities such as anticancer, anticholinesterase, anti-inflammatory, antimicrobial, antioxidant of essential oils obtained from the flowers have been studied [15, 18, 27-29].

The aim of this study was to determine whether or the samples in different cities of Turkey sold with the name of "gül" carry qualities appropriate for the definition of herbal drug. In this context, the rose samples were obtained from five different cities in Turkey. The samples were examined morphologically and microscopically for the purpose of our study. Based on the findings, the identities and qualifications of the samples were evaluated.

\section{RESULTS}

\subsection{The usage and the conditions of sales}

According to the findings obtained from face-to-face interviews, it has been determined that the drug is usually used in form of the infusion for stomach pain, upper respiratory tract, insomnia, detoxification and, as sedative and flavoring. It was observed that the samples sold in the market with the name of "gül" were usually sold in open conditions so without packaging, but they were more sold in packages in Ankara.

\subsection{Morphological results}

The flowers consist of 5 sepals and numerous petals, stamens, styles, and carpels. The sepal is lanceolate and green. Petal is deep pink and broadly ovate (Figure 6a-c). Morphological findings obtained from the samples are present in Table 1 and Figures 1 and 6d-o. Morphological studies have shown that the samples are usually composed of rosebuds. The bud length in the range of 1.1 to $3 \mathrm{~cm}$ and calyx length in the range of 1 to $2.5 \mathrm{~cm}$ were determined in the samples. The samples in $\mathrm{G} 2$ and $\mathrm{K}$ locations differ in content and color from the other samples. It was usually observed that there are samples exposed to fungal infection and eaten by insects. While the foreign matter was not observed in the samples, parts of the other plants were observed in A2, G2, I2, and IZ1 locations. The insect was seen in I2 and IZ2 locations. Besides, apart from the herbal drug no other substance was observed in the A3, G1, and I3 locations (Table 1).
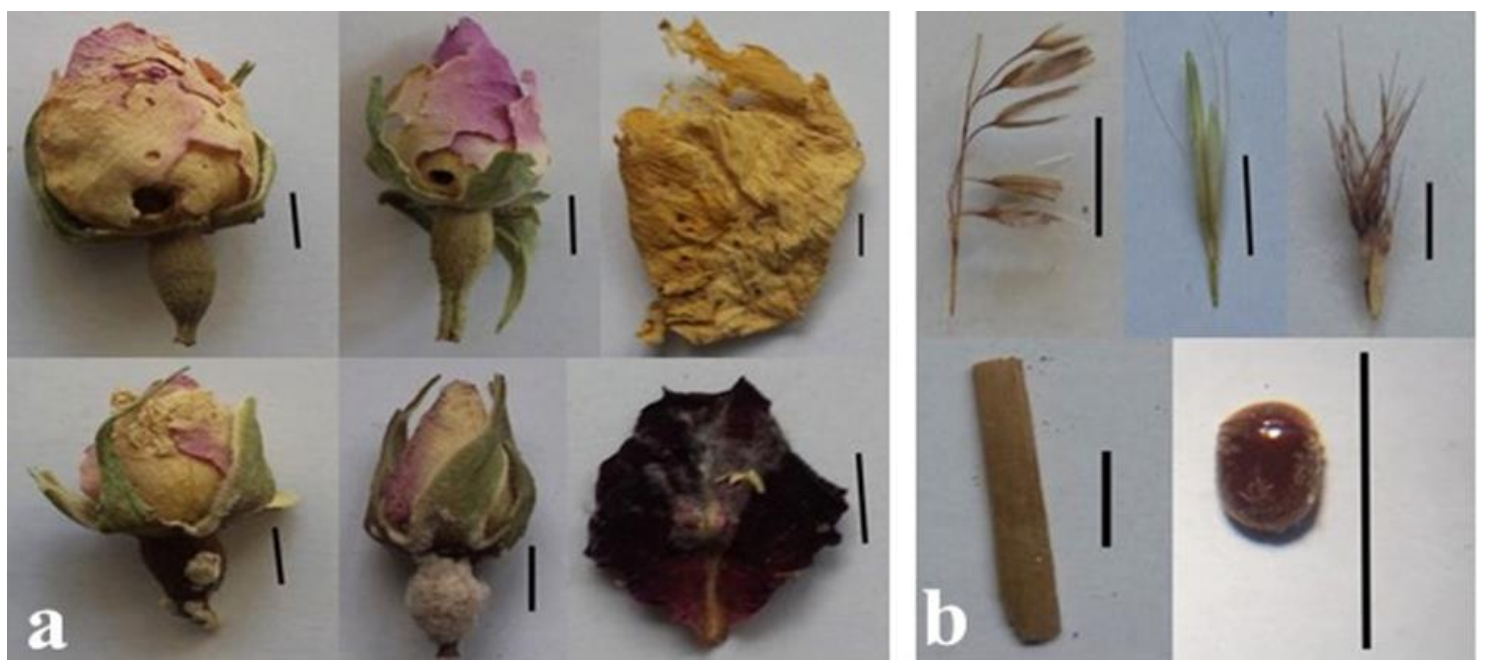

Figure 1.a. "Gül" samples with exposed to fungal infection and eaten by insects, b. Parts of other plants and insect. Scale bars: $5 \mathrm{~mm}$. 
Table1. Morphological characteristics of the "Gül” samples.

\begin{tabular}{|c|c|c|c|c|}
\hline Sample & General appearance & $\begin{array}{l}\text { Budlength } \\
\text { (cm) }\end{array}$ & $\begin{array}{l}\text { Calyx } \\
\text { length } \\
(\mathrm{cm})\end{array}$ & $\begin{array}{l}\text { The proportion } \\
\text { of non-drugs } \\
\text { items }\end{array}$ \\
\hline A1 & $\begin{array}{l}\text { Usually fresh pink rosebuds, however, there } \\
\text { are buds exposed to fungal infection and eaten } \\
\text { by insects. }\end{array}$ & $1.8-2.5$ & 1.1-1.6 & $\begin{array}{l}1 \% \text { fragments of } \\
\text { branches }\end{array}$ \\
\hline A2 & $\begin{array}{l}\text { Usually fresh pink rosebuds, however, there } \\
\text { are buds exposed to fungal infection. }\end{array}$ & $2-2.6$ & $1.3-1.7$ & $\begin{array}{l}1 \% \text { other plant } \\
\text { parts }\end{array}$ \\
\hline A3 & $\begin{array}{l}\text { Usually fresh pink rosebuds, however, there } \\
\text { are buds exposed to fungal infection and eaten } \\
\text { by insects. }\end{array}$ & $1.8-2.7$ & $1-1.6$ & - \\
\hline A4 & $\begin{array}{l}\text { Usually fresh pink rosebuds, however, there } \\
\text { are buds eaten by insects }\end{array}$ & $2-2.6$ & $1.3-1.8$ & $\begin{array}{l}1 \% \text { fragments of } \\
\text { branches }\end{array}$ \\
\hline G1 & $\begin{array}{l}\text { Usually fresh pink rosebuds, however, there } \\
\text { are buds eaten by insects. }\end{array}$ & $2-3.2$ & $1.2-2$ & 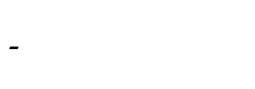 \\
\hline G2 & $\begin{array}{l}\text { It usually consists of red fragmented petals, } \\
\text { calyx samples, and rarely pink rosebuds. } \\
\text { There are samples exposed to fungal infection } \\
\text { and eaten by insects. }\end{array}$ & - & $1.3-1.9$ & $\begin{array}{l}1 \% \text { fragments of } \\
\text { branches, } 1 \% \\
\text { fragments of } \\
\text { leaves, } 1 \% \text { other } \\
\text { plant parts }\end{array}$ \\
\hline I1 & $\begin{array}{l}\text { Usually fresh pink rosebuds, however, there } \\
\text { are buds eaten by insects. }\end{array}$ & $2-2.5$ & $1.3-1.5$ & $\begin{array}{l}1 \% \text { fragments of } \\
\text { branches }\end{array}$ \\
\hline I2 & $\begin{array}{l}\text { Usually pink rosebuds, however, there are } \\
\text { buds exposed to fungal infection and eaten by } \\
\text { insects. }\end{array}$ & $1.9-3$ & $1.1-2$ & $\begin{array}{l}1 \% \text { other plant } \\
\text { parts, insect was } \\
\text { seen }\end{array}$ \\
\hline I3 & $\begin{array}{l}\text { Usually pink rosebuds, however, there are } \\
\text { buds exposed to fungal infection and eaten by } \\
\text { insects. }\end{array}$ & 1.1-1.5 & $2-2.5$ & 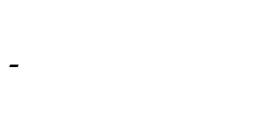 \\
\hline IZ1 & $\begin{array}{l}\text { Usually pink rosebuds, but there are buds } \\
\text { exposed to fungal infection and eaten by } \\
\text { insects. }\end{array}$ & $2-3$ & $1-1.8$ & $\begin{array}{l}1 \% \text { other plant } \\
\text { parts }\end{array}$ \\
\hline IZ2 & $\begin{array}{l}\text { Usually pink rosebuds and fragmented petals, } \\
\text { however, there are buds exposed to fungal } \\
\text { infection and eaten by insects. }\end{array}$ & $1.8-3$ & $1.2-1.9$ & $\begin{array}{l}1 \% \text { fragments of } \\
\text { branches, insect } \\
\text { was seen }\end{array}$ \\
\hline $\mathbf{K}$ & $\begin{array}{l}\text { It usually consists of red and white petals, but } \\
\text { there are samples exposed to fungal infection } \\
\text { and eaten by insects }\end{array}$ & - & - & $\begin{array}{l}1 \% \text { fragments of } \\
\text { leaves }\end{array}$ \\
\hline
\end{tabular}

\subsection{Anatomical results}

\subsubsection{Cross and surface sections of the sepal}

In this part, we were taken cross and surface sections from the sepal. In cross-section, upper and lower epidermis with one layer and irregularly shaped cells are covered with thick of cuticle. The mesophyll layer located between the lower and upper epidermis consists only of spongy parenchyma cells. Intercellular space is not too much in the spongy parenchyma. A few layers of collenchyma cells are observed beneath the lower and upper epidermis. Druses and prismatic crystals were observed as calcium oxalate crystals. Prismatic crystals were rarely observed while druses are found densely. Vascular bundles consist of phloem at the top and xylem at the bottom and surrounded by sclerenchyma. Unicellular non-glandular trichomes with a thick cuticle were observed densely. Glandular trichomes are multicellular capitate and long-stalked (Figure 2a-c). In the abaxial surface of the section, the epidermis occurs from irregularly shaped cells with slightly sinuous walls. Densely druses and rarely prismatic crystals were showed on this surface. Besides, unicellular non-glandular trichomes with a thick cuticle were scattered (Figure $2 \mathrm{~d}-\mathrm{e}$ ). In the adaxial surface of the section, the epidermis is composed of irregularly shaped cells with slightly sinuous walls. The stomata are anomocytic with 3-6 subsidiary cells. Capitate glandular hairs with multicellular and long-stalked with multicellular were seen. Also, unicellular non-glandular trichomes with thick cuticle were found densely (Figure 2f-g). 

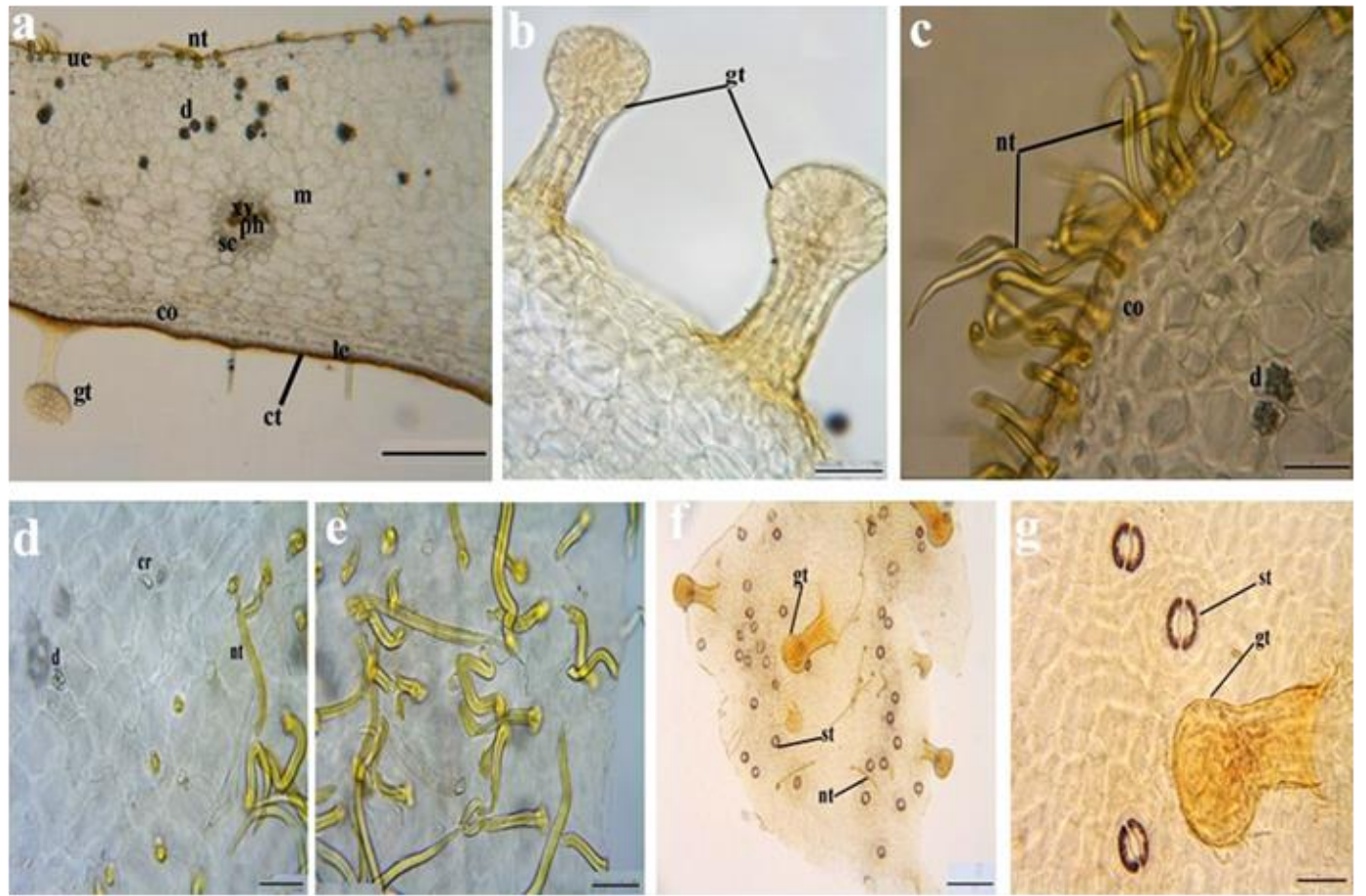

Figure 2. Rosa damascena sepal a. Cross-section general view, b. Glandular hair, c.Trichomes and druses. Abaxial surface section d. Druses, crystal and trichomes, e. Trichomes. Adaxial surface section f. General view, g. Glandular hair and stomata. Scale bars: a, f, $200 \mu \mathrm{m} ; \mathrm{b}-\mathrm{e}, \mathrm{g}, 50 \mu \mathrm{m}$.

Abbreviations: co, collenchyma; cr, crystal; ct, cuticle; d, druse; gt, glandular trichome; le, lower (abaxial) epidermis; m, mesophyll; nt, non-glandular trichome; ph, phloem; sc, sclerenchyma; st, stoma; ue, upper (adaxial) epidermis; $x y$, xylem.

\subsubsection{Cross and surface sections of the petal}

In the cross-section, the upper (adaxial) and lower (abaxial) epidermis are uniseriate and rectangular. Conical papillae are seen especially on the lower epidermis. The mesophyll consists usually of orbicular or irregular shaped-cells, loosely-arranged. In the mesophyll section, the vascular bundles are seen. Unicellular non-glandular trichomes with a thick cuticle are seen densely. Also, especially in this section, the druses are encountered rarely (Figure 3).

In the abaxial surface section, the abaxial epidermis has conical papillae in especially at the apex. In the lower sections, the cuticular striations are observed. Unicellular non-glandular trichomes are seen intensely. Glandular trichomes are seen rarely. Anomocytic stomata with 5-7 subsidiary cells are observed (Figure 4a-d). In the adaxial surface section, conical papillae in especially at the apex are seen in the abaxial epidermis. In the inner section, a striated cuticle is observed densely. The simple unicellular trichomes are located densely. Anomocytic stomata (5-7 subsidiary cells) are seen (Figure 4e-g).
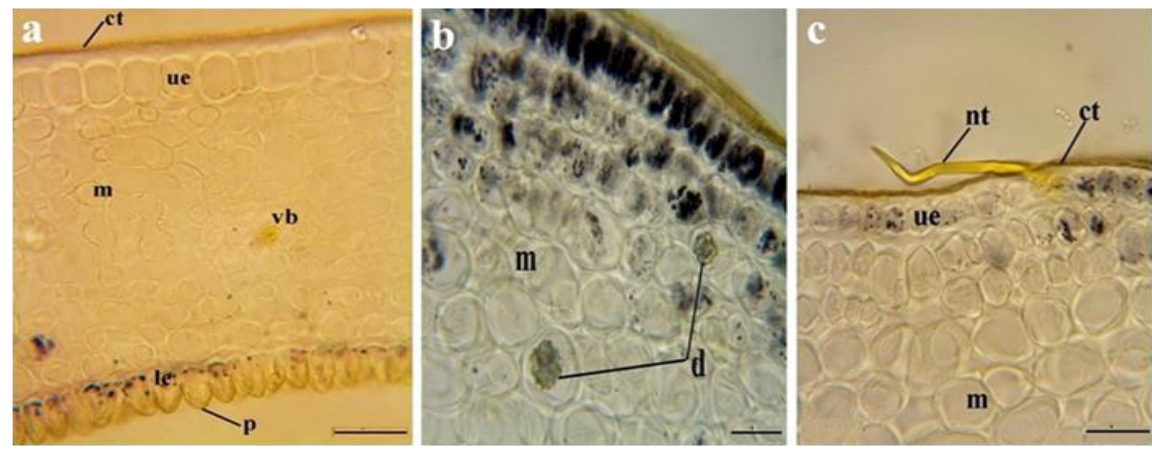

Figure 3. Rosa damascena petal a. Cross-section general view, b. Druses in the mesophyll, c. Non-glandular trichome. Scale bars: $50 \mu \mathrm{m}$.

Abbreviations: ct, cuticle; d, druse; le, lower (abaxial) epidermis; m, mesophyll; nt, non-glandular trichome; $\mathrm{p}$, papillae; ue, upper (adaxial) epidermis; vb, vascular bundle. 

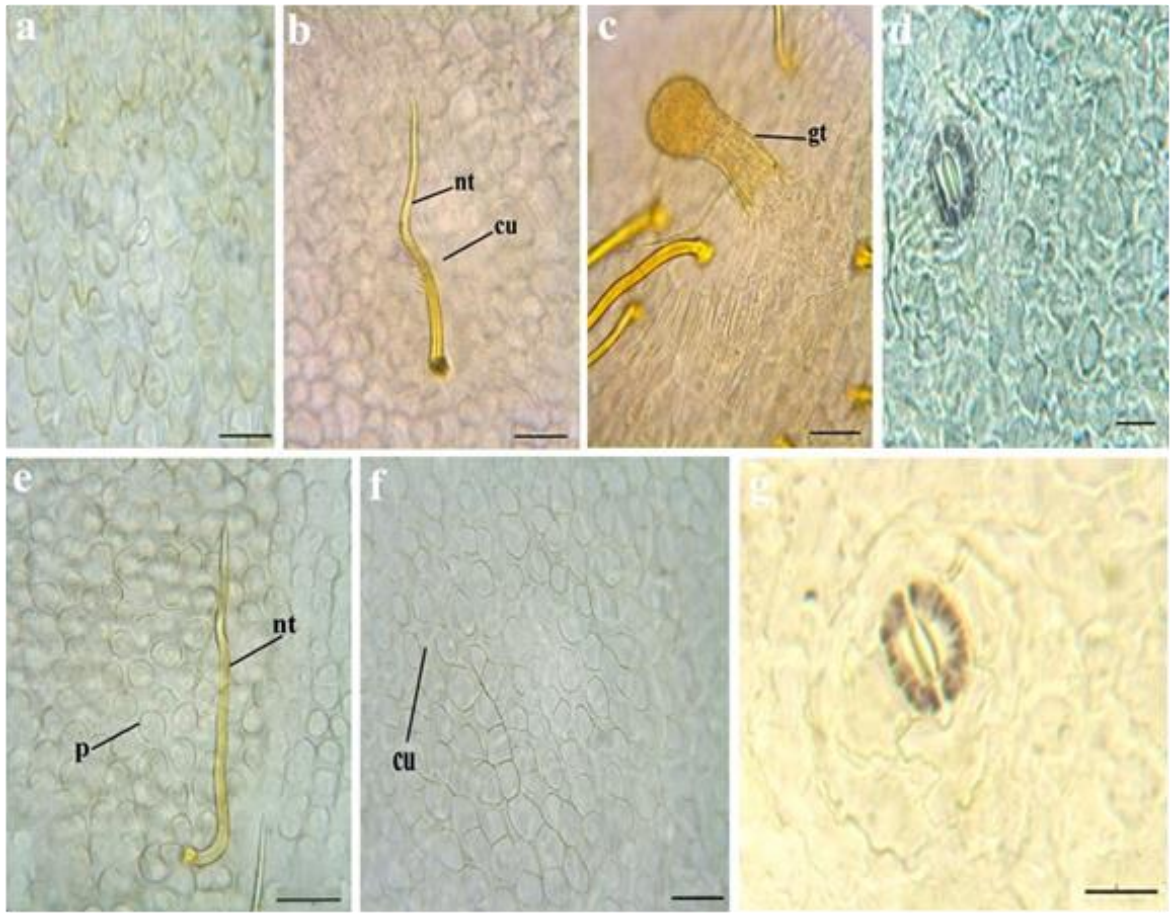

Figure 4. The abaxial surface section of Rosa damascena petal a. Epidermis with conical papillae, b. Nonglandular trichome and striated cuticle, c. Glandular trichome, d. Stoma. The adaxial surface section of Rosa damascena petal e. Epidermis with conical papillae and non-glandular trichome; f. Striated cuticle with epidermis; g. Stoma. Scale bars: a-c, e, f, $50 \mu \mathrm{m} ; \mathrm{d}, \mathrm{g}, 20 \mu \mathrm{m}$.

Abbreviations: cu, cuticle striation; gt; glandular hair; nt, non-glandular trichome; $\mathrm{p}$, papillae.

\subsection{Examination of the powdered drug}

It was determined that all of the examined powdered drugs are heterogeneous and in pink-green color apart from G2 and K locations. Red-green color in G2 location and red-white color in K location were observed. All samples were found to have an aromatic odor and taste. Also, the characteristic anatomical elements of samples were defined and showed in Figure 5.
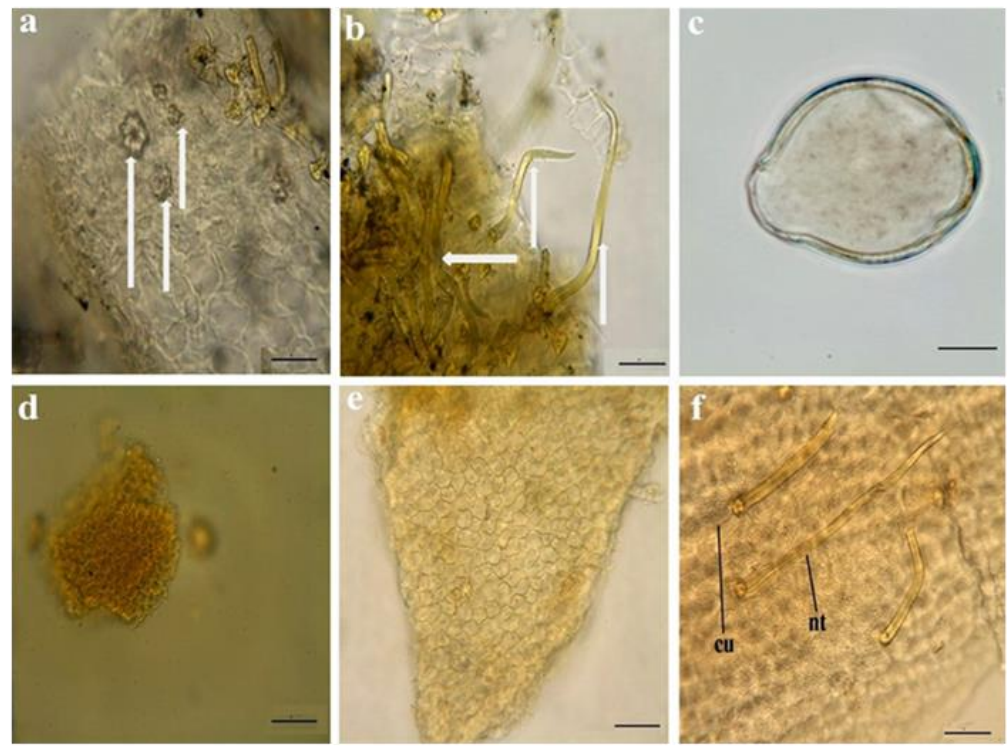

Figure 5. Microscopic properties of the powdered samples a. Druses in the sepal epidermis, b. Trichomes in the sepal epidermis, c. Pollen, $\mathbf{d}$. Petal epidermis, e. Conical papillae with epidermal cells in the petal, $\mathbf{f}$. Non-glandular trichomes and striated cuticle epidermis in the petal.

Scalebars: a, b, d-f, $50 \mu \mathrm{m} ; \mathrm{f}, 10 \mu \mathrm{m}$. 


\section{DISCUSSION}

Rosa damascena is very important economically in Turkey. Rose flowers (fresh or dried), rose flower buds, dry rose petals, and rose products are utilized in cosmetic, perfumery, and food industries (rose jam, rose syrup, rose water, traditional Turkish desserts, herbal teas, etc.) [30]. In this study, we collected the samples which in different cities of Turkey sold with the name of "gül". We conducted morphological and anatomical research on these samples. We checked whether or they possess the appropriate features of the term herbal drug with these studies.

It was determined that all of the examined powdered drugs are heterogeneous and in pink-green color apart from G2 and K locations. The red color in G2 location and red-white color in K location were observed. All samples were found to have an aromatic odor and taste. Also, the characteristic anatomical elements of samples were defined and showed in Figure 5.

It was determined that the samples sold in the market under the name of "gül" were generally sold in open conditions but they were mostly sold in packages in Ankara. It has been determined that the drug is usually used as an infusion for stomach pain, upper respiratory tract, insomnia, detoxification, and as sedative and flavour in direction with findings obtained from the drug sellers. This information is consistent with the literature $[10,11,12]$. Morphological studies have shown that the samples are usually composed of rosebuds. The samples in G2 and K locations differ in content and color from the other samples. The samples with red color in G2 location and the samples with red and white colors in K location were observed. It was usually seen that there are samples exposed to fungal infection and eaten by insects. Foreign matters were not determined in the samples, but the parts of other plants were observed in A2, G2, I2, and IZ1 locations. Also, no other substances apart from the drug were seen in the A3, G1, and I3 locations (Table 1).

In anatomical examinations, firstly, the anatomical structures of the sepal and petal samples were illuminated using the standard sample. Simple unicellular non-glandular trichomes and druses were densely observed in the sepal. Druses were determined on the abaxial surface of the sepal and rarely crosssection of the petal. Glandular hairs with multicellular head and stalk were observed on the outer surface of the sepal. Also, glandular hairs were rarely seen on the abaxial surface of the petal. Stomata (3-6 subsidiary cells) were present on the adaxial surface of the sepal. Stomata (5-7 subsidiary cells) and dense nonglandular trichomes were observed on both surfaces of the petal. Conical papillae with epidermal cells were seen on the petal. The cuticular striations were observed on both surfaces of the petal (Figures 2-4). "Isparta gülü" was recorded as "Rosa damascena petals (Isparta gülü taç yaprakları)" in Turkish Pharmacopoeia 2017. This drug is obtained from the petals, separated from the hypanthium and the other flower organs (sepals, male and female organs), dried, powdered. In this monograph, morphological and anatomical features of rose petals are given. The petals have been described in shapes ranging from narrow ovate to broad cordate in Turkish Pharmacopoeia. The powdered drug consisting of petals is pale dark pink with a prominent rose scent. The samples purchased from the market, consists usually of pink rosebuds apart from G2 and K locations. Unlike Turkish Pharmacopeia, the presence of druses and glandular hairs in the petal of the standard sample was seen [31]. The anatomical structure of Rosa damascena flowers was shown similarity with Rosa rugosa thunb. flowers in terms of glandular hair structures, druses, papillae with the petal surface, cuticular striations on the petal surface [32]. Besides, no different findings were observed in the powdered drug samples purchased from the market and standard sample with the conducted anatomical studies.

Herbal drugs don't contain, many impurities such as soil, dust, fungus, insects, and other animal contaminants. They're not rotten. If the contaminants are removed from the herbal drugs, the components of the plant must be shown to be unaffected and free of harmful waste [33].

Sometimes the herbal samples sold in the market do not represent the correct plant. Care should be taken in this regard. Also, the hygiene issue of herbal samples sold in open conditions is controversial because these samples can be exposed to microbial and chemical contamination. The sale of herbal samples should be done by conscious and trained people and the inspections should be carried out.

\section{CONCLUSIONS}

In the study, we conducted on the samples sold in the market, we found that the samples were correct. However, the investigated samples do not carry the proper conditions or qualifications according to herbal drug description.

\section{MATERIALS AND METHODS}

Twelve different samples were obtained from the markets in 5 different cities of Turkey, Ankara (4), Gaziantep (2), İstanbul (3), İzmir (2), Kahramanmaraş (1). The standard sample was supplied from the culture form in Isparta (AEF 26992) (Table 2). Information about the aim of using herbal drugs the drug 
sellers were obtained. The morphological characteristics of all samples were examined and, impurities in all samples were determined. Photos of the samples and impurities were taken (Sony Cyber-shot DSC-S5000) (Figure 6). For the microscopic studies, cross and surface sections from the sepals and petals of the standard sample were prepared using Sartur reagent at least 50 different samples with the hand [34, 35], and the photos on the light microscope (Leica CME) were taken with a Leica DFC280 camera. Also, the distinguishing anatomical characteristics of the samples in powder form (standard sample and samples obtained from the market) were determined.

Table2. Locations of the studied samples.

\begin{tabular}{|c|c|c|}
\hline Location & Sample & Figure number \\
\hline Ankara 1 & A1 & Figure. $6 \mathrm{~d}$ \\
\hline Ankara 2 & A2 & Figure. 6e \\
\hline Ankara 3 & A3 & Figure. $6 f$ \\
\hline Ankara 4 & A4 & Figure. $6 \mathrm{~g}$ \\
\hline Gaziantep 1 & G1 & Figure. $6 \mathrm{~h}$ \\
\hline Gaziantep 2 & G2 & Figure. 61 \\
\hline İstanbul 1 & I1 & Figure. $6 \mathrm{j}$ \\
\hline İstanbul 2 & $\mathrm{I} 2$ & Figure. 6k \\
\hline İstanbul 3 & $\mathrm{I} 3$ & Figure. 61 \\
\hline İzmir 1 & IZ1 & Figure. $6 \mathrm{~m}$ \\
\hline İzmir 2 & IZ2 & Figure. 6n \\
\hline Kahramanmaraş & $\mathrm{K}$ & Figure. 60 \\
\hline Standard & $\begin{array}{c}\text { St } \\
\text { Cultured form from Isparta } \\
\text { (AEF 26992) }\end{array}$ & Figure. 6a-c \\
\hline
\end{tabular}
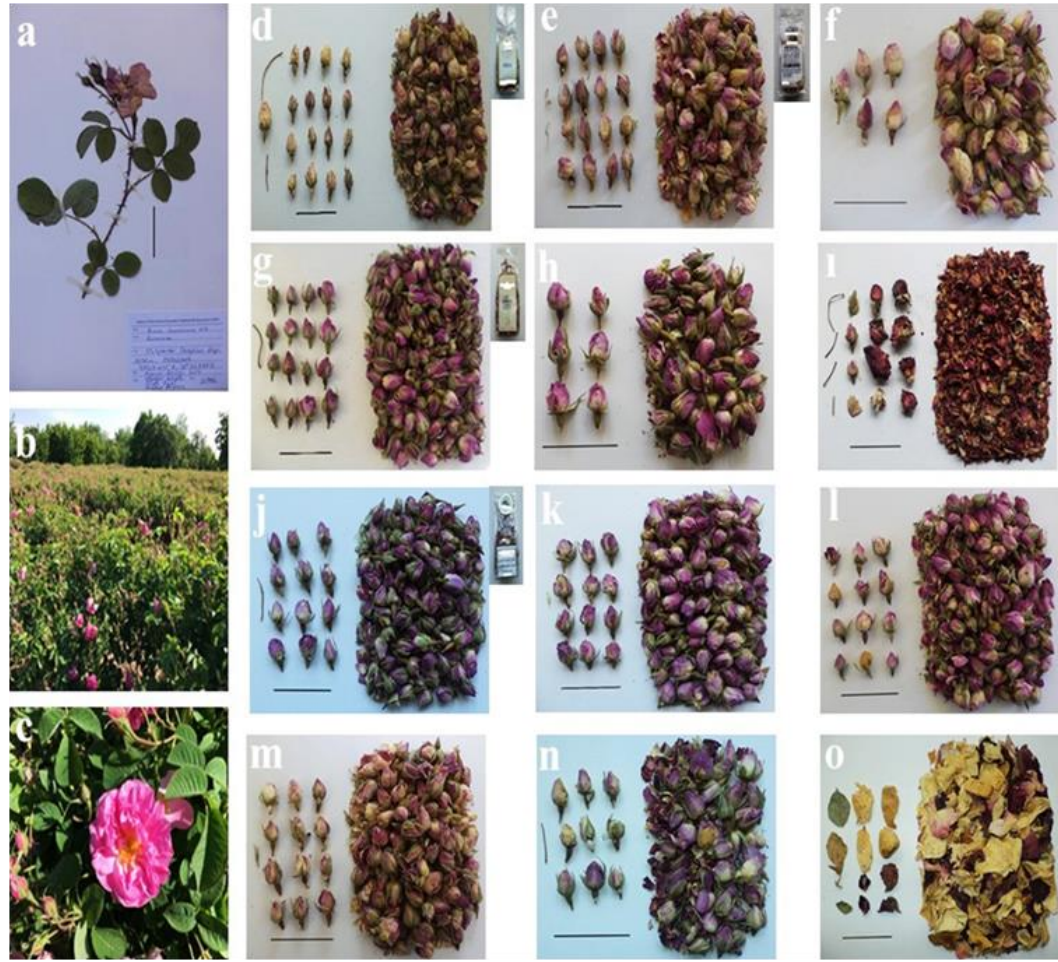

Figure 6. a. Rosa damascena herbarium sample, b-c. Cultivated samples, d-g. Samples from the markets in Ankara, h-1. Samples from the markets in Gaziantep, j-1. Samples from the markets in İstanbul, m-n. Samples from the markets in İzmir, o. Sample from the market in Kahramanmaraş.

Scale bars: a, d-o, $5 \mathrm{~cm}$. 
Acknowledgements: This study was not supported financially.

Author contributions: Concept -A.K.; Design - A. K, G.K.; Supervision - A.K., G.K.; Resource - G.K.; Materials G.K.; Data Collection and/or Processing - G.K.; Analysis and/or Interpretation - A.K., G.K.; Literature Search -G.K.; Writing -G.K.; Critical Reviews - A.K., G.K.

Conflict of interest statement: The authors declare that there are no conflicts of interest.

\section{REFERENCES}

[1] Boskabady M, Shafei M, Saberi Z, Amini S. Pharmacological effects of Rosa damascena. Iran J Basic Med Sci. 2011; 14: 295-307.

[2] Örmeci Kart M, İkiz M, Demircan V. Türkiye' de yağ gülü (Rosa damascena) üretimi ve ticaretinin gelişimi. Süleyman Demirel Üniversitesi Ziraat Fakültesi Dergisi. 2012; 7: 124-134.

[3] Nayebi N, Khalili N, Kamalinejad M, Emtiazy M. A systematic review of the efficacy and safety of Rosa damascena Mill. with an overview on its phytopharmacological properties. Complement Ther Med. 2017; 34: 129140.[CrossRef]

[4] Ercisli S. Rose (Rosa spp.) germplasm resources of Turkey. Genet Resour Crop Evol. 2005; 52: 787-795.

[5] Mahboubi M. Rosa damascena as holy ancient herb with novel applications. J Tradit Complement Med. 2016; 6: 1016. [CrossRef]

[6] Ivancheva S, Stantcheva B. Ethnobotanical inventory of medicinal plants in Bulgaria. J Ethnopharmacol. 2000; 68: 165-172.[CrossRef]

[7] Baydar H. Oil-bearing rose (Rosa damascena Mill.) cultivation and rose oil industry in Turkey. Euro Cosmetics. 2006; 14: 13-17.

[8] Baytop T. Bitki Adları Sözlüğü. Atatürk Kültür, Dil ve Tarih Yüksek Kurumu Türk Dil Kurumu Yayınları: 578 , 3. bask1, Ankara, 2007.

[9] Türkiye İstatistik Kurumu, Bilgi Dağıtım ve İletişim Daire Başkanlığı, Bilgi Dağıtım Grubu, bilgi@tuik.gov.tr, Dış Ticaret İstatistikleri-Tüik https:/ / biruni.tuik.gov.tr/disticaretapp/menu.zul (accessed on 21 December 2018).

[10] Ercişli S, Güleryüz M. Rose Hip utilization in Turkey. Proceedings of I. International Rose Hip Conference, Acta Hortic. 2005; 690: 77-82.

[11] Dogan A, Bulut G, Senkardes I, Tuzlacı E. An ethnopharmacological analysis of Rosaceae taxa in Turkey. WEI International Academic Conference Proceedings. Boston. USA. 2016; 44-51.

[12] Tuzlacı E. Türkiye Bitkileri Geleneksel İlaç Rehberi. İstanbul Tıp Kitabevleri, İstanbul, 2016.

[13] Mikanagi Y, Saito N, Yokoi M, Tatsuzawa F. Anthocyanins in flowers of genus Rosa, sections Cinnamomeae (=Rosa), Chinenses, Gallicanae and some modern garden roses. Biochem Syst Ecol. 2000; 28(9): 887-902. [CrossRef]

[14] Kumar N, Bhandari P, Singh B, Bari SS. Antioxidant activity and ultra-performance LC-electrospray ionizationquadrupole time-of-flight mass spectrometry for phenolics-based fingerprinting of Rose species: Rosa damascena, Rosa bourboniana and Rosa brunonii. Food Chem Toxicol. 2009; 47: 361-367.[CrossRef]

[15] Mahboubi M, Kazempour N, Khamechian T, Fallah MH, Kermani MM. Chemical composition and antimicrobial activity of Rosa damascena Mill essential oil. Journal of Biologically Active Products from Nature. 2011; 1(1): 19-26. [CrossRef]

[16] Baydar NG, Baydar H. Phenolic compounds, antiradical activity and antioxidant capacity of oil-bearing rose (Rosa damascena Mill.) extracts. Ind Crops Prod. 2013; 41: 375-380. [CrossRef]

[17] Halawani EM. Antimicrobial activity of Rosa damascena petals extracts and chemical composition by gas chromatography-mass spectrometry (GC/MS) analysis. Afr J Microbiol Res. 2014; 8(24): 2359-2367. [CrossRef]

[18] Mileva M, Krumova E, Miteva-Staleva J, Kostadinova N, Dobreva A, Galabov AS. Chemical compounds, in vitro antioxidant and antifungal activities of some plant essential oils belonging to Rosaceae family. CR Acad Bulg Sci. 2014; 67(10), 1363-1368.

[19] Memariani Z, Amin GH, Moghaddam GH, Hajimahmoodi M. Comparative analysis of phenolic compounds in two samples of Rosa damascena by HPLC. International Journal of Biosciences. 2015; 7: 112-118. [CrossRef] 
[20] Zaidi SF, Muhammad JS, Shahryar S, Usmanghani K, Gilani AH, Jafri W, Sugiyama T. Anti-inflammatory and cytoprotective effects of selected Pakistani medicinal plants in Helicobacter pylori-infected gastric epithelial cells. J Ethnopharmacol. 2012; 141(1): 403-410. [CrossRef]

[21] Jazayeri SB, Amanlou A, Ghanadian N, Pasalar P, Amanlou M. A preliminary investigation of anticholinesterase activity of some Iranian medicinal plants commonly used in traditional medicine. Daru. 2014; 22 (1): 17. [CrossRef]

[22] Esmaeili S, Ghiaee A, Naghibi F, Mosaddegh M. Antiplasmodial activity and cytotoxicity of plants used in traditional medicine of Iran for the treatment of fever. Iran J Pharm Res. 2015; 14(Suppl): 103-107.

[23] Artun FT, Karagoz A, Ozcan G, Melikoglu G, Anil S, Kültür S, Sutlupinar N. In vitro anticancer and cytotoxic activities of some plant extracts on HeLa and Vero cell lines. JBUON. 2016; 21(3): 720-725.

[24] Gholamhoseinian A, Fallah H, Sharifi far F. Inhibitory effect of methanol extract of Rosa damascena Mill. flowers on a-glucosidase activity and postprandial hyperglycemia in normal and diabetic rats. Phytomedicine. 2009; 16(10): 935-941.[CrossRef]

[25] Dolati K, Rakhshandeh H, Shafei MN. Evaluation of antidepressant effect of ethanolic extract of Rosa damascena using forced swimming test. Avicenna J Phytomed. 2011; 2(1): 46-51.[CrossRef]

[26] Esfandiary E, Karimipour M, Mardani M, Ghanadian M, Alaei HA, Mohammadnejad D, Esmaeili A. Neuroprotective effects of Rosa damascena extract on learning and memory in a rat model of amyloid- $\beta$-induced Alzheimer's disease. Adv Biomed Res. 2015; 4: 131.[CrossRef]

[27] Latifi G, Ghannadi A, Minaiyan M. Anti-inflammatory effect of volatile oil and hydroalcoholic extract of Rosa damascena Mill. on acetic acid-induced colitis in rats. Res Pharm Sci. 2015; 10(6): 514-522.

[28] Rezaie-Tavirani M, Fayazfar S, Heydari-Keshel S, Rezaee MB, Zamanian-Azodi M, Rezaei-Tavirani M, Khodarahmi R. Effect of essential oil of Rosa damascena on human colon cancer cell line SW742. Gastroenterol Hepatol Bed Bench. 2013; 6(1): 25-31.

[29] Senol FS, Orhan IE, Kurkcuoglu M, Khan MTH, Altintas A, Sener B, Baser KHC. A mechanistic investigation on anticholinesterase and antioxidant effects of rose (Rosa damascene Mill.). Food Res Int. 2013; 53: 502-509.[CrossRef]

[30] Gül H, Tekeli SG.. Inclusion of Rosa damascena Mill. powder into cookies: nutritional, antioxidant and quality characteristics. Int J Agric For Life Sci. 2019; 3(2): 301-306.

[31] Türk Farmakopesi 2017. Genel monograflar IV, TC Sağlık Bakanlıgı Yayın No: 1098, 1. Baskı, Ankara, 2018 b.

[32] Sulborska A, Weryszko-Chmielewska E. Characteristics of the secretory structures in the flowers of Rosa rugosa Thunb. Acta Agrobot. 2014; 67(4): 13-24. [CrossRef]

[33] European Pharmacopoeia, 8th edition. Volume 1. Strasbourg: Council of Europe, 2013.

[34] Çelebioğlu S, Baytop T. Bitkisel tozların tetkiki için yeni bir reaktif. Farmakognozi Enstitüsü Yayınları, No. 10. Farmakolog 1949; 19: 301.

[35] Türk Farmakopesi 2017. Genel monograflar II, TC Sağlık Bakanlıg1 Yayın No: 1098, 1. Baskı, Ankara, $2018 a$. 